\title{
A review on Lactococcus lactis: from food to factory
}

\author{
Adelene Ai-Lian Song ${ }^{1 *}$, Lionel L. A. In², Swee Hua Erin Lim³ ${ }^{3}$ and Raha Abdul Rahim ${ }^{4}$
}

\begin{abstract}
Lactococcus lactis has progressed a long way since its discovery and initial use in dairy product fermentation, to its present biotechnological applications in genetic engineering for the production of various recombinant proteins and metabolites that transcends the heterologous species barrier. Key desirable features of this gram-positive lactic acid non-colonizing gut bacteria include its generally recognized as safe (GRAS) status, probiotic properties, the absence of inclusion bodies and endotoxins, surface display and extracellular secretion technology, and a diverse selection of cloning and inducible expression vectors. This have made L. lactis a desirable and promising host on par with other well established model bacterial or yeast systems such as Escherichia coli, Salmonella cerevisiae and Bacillus subtilis. In this article, we review recent technological advancements, challenges, future prospects and current diversified examples on the use of L. lactis as a microbial cell factory. Additionally, we will also highlight latest medical-based applications involving whole-cell L. lactis as a live delivery vector for the administration of therapeutics against both communicable and non-communicable diseases.
\end{abstract}

Keywords: Lactococcus lactis, Heterologous proteins, Recombinant proteins, Expression systems, Secretion, Surface display, Microbial cell factory

\section{Background}

Despite the common association of Lactococcus lactis with dairy products, the bacterium was originally isolated from plants where it was believed to be dormant, and only became active and multiplied in the gastrointestinal tract after being consumed by ruminants [1]. Originating from the streptococcus genus and re-classified into the Lactococcus genus in 1985, L. lactis is divided into three subspecies namely $L$. lactis subsp. lactis, L. lactis subsp. cremoris, and L. lactis subsp. hordniae [2]. Phenotypically, it is classified as a gram-positive, spherical, homolactate, non-sporulating, and facultative anaerobic gut bacteria with hundreds of strains and biovariants published to date $[3,4]$.

Lactococcus lactis has been used for centuries in the fermentation of food especially cheese, yoghurt, sauerkraut and the like, thereby rendering it's generally

\footnotetext{
*Correspondence: adelene@upm.edu.my

1 Department of Microbiology, Faculty of Biotechnology \& Biomolecular Sciences, University Putra Malaysia, 43400 Serdang, Selangor, Malaysia Full list of author information is available at the end of the article
}

recognized as safe (GRAS) status by the Food and Drug Administration (FDA). Apart from imparting flavour, $L$. lactis being a lactic acid bacteria (LAB) also produces acid which preserves food. Some strains further enhances this preservation property with the production of bacteriocins, thus reinforcing its role in the food industry. Other than its important function in food, L. lactis has become the model LAB when it comes to genetic engineering. Several factors including its small-sized fully sequenced genome $(2.3 \mathrm{Mbp})$, and the development of successfully compatible genetic engineering tools such as cloning and expression systems with customizable options, have rendered it a desirable model. Over the past two decades, $L$. lactis has vastly extended its application from food to being a successful microbial cell factory (Fig. 1a), and on many occasions, acting as a gram-positive alternative to Bacillus subtilis and Lactobacillus plantarum, or its gram-negative counterpart, Escherichia coli (Fig. 1b) [5].

This review will cover the many aspects of $L$. lactis as a cell factory for an immense range of products as well as its role as a vehicle for delivery of therapeutics into the gastrointestinal system. It is to be used as an overview of 


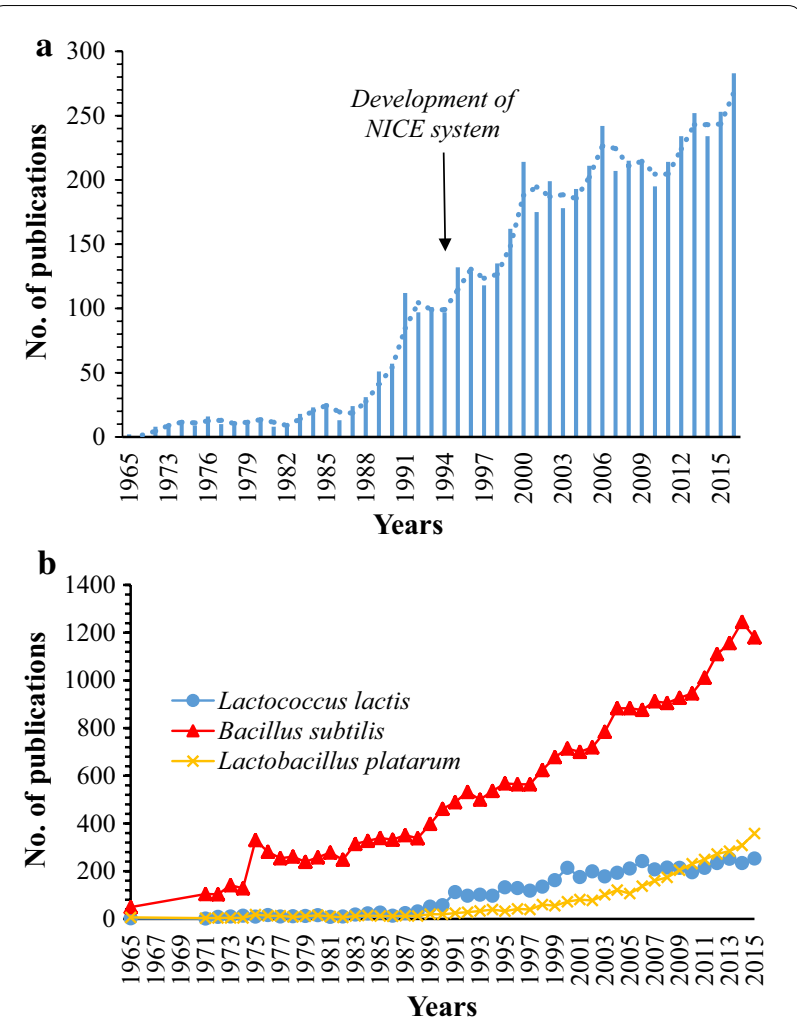

Fig. 1 a Graph indicating an increasing trend of publications relating to Lactococcus lactis technological advancements and research. b Comparison of publications between Gram positive model organisms-Bacillus subtilis, Lactobacillus plantarum and Lactococcus lactis over the past 50 years

the enormously extended biotechnological role that $L$. lactis has so far acquired, indicating other relevant and niche areas involving L. lactis where applicable.

\section{The lactococcal molecular toolbox}

\section{Expression systems}

One of the reasons $L$. lactis has emerged to become a successful microbial cell factory system is due to the wealth of genetic knowledge available spanning at least four fully sequenced lactococcal strains [6] and many existing expression systems. Various constitutive and inducible expression systems have been developed for L. lactis as screening of promoters using reporter genes such as beta-galactosidase are a commonly used strategy in developing novel lactococcal expression systems [7, 8]. P45 and P32 are commonly used as constitutive lactococcal promoters, but stronger promoters are still being discovered and developed to improve the system [9].

In most cases, inducible promoters are preferred over constitutive promoters as they provide better control to the user. There are various lactococcal inducible systems such as $\mathrm{P}_{(\mathrm{Zn}) z i t R}$ and Zirex system which are both regulated based on zinc availability where the former and latter are repressed and induced by the presence of zinc, respectively [10]. Other inducible promoters are PA170 which is induced by a decrease in $\mathrm{pH}$ during transition of culture to stationary phase thus making it autoinducible $[11,12]$ and $\mathrm{P}_{x y l T}$ which is induced by xylose [13]. However, without doubt, the most successful lactococcal expression system to date is the nisin controlled gene expression (NICE) system developed by Kuipers and colleagues in 1995. Nisin is a 34-amino acid anti-microbial peptide whose biosynthesis is encoded by a cluster of 11 genes. Of the 11 genes, nisR and nisK regulate expression of the nisin genes. NisK is a histidine-protein kinase which resides in the cytoplasmic membrane and acts as a receptor for the nisin molecule. Upon reception of nisin, it activates nisR via phosphorylation, which in turn induces transcription of two promoters in the nisin gene cluster: PnisA and PnisF [14].

The host $L$. lactis NZ9000 is a derivative of the nisinnegative MG1363 strain with the nisR and nisK genes inserted into its chromosome [15]. When a gene of interest is placed downstream the PnisA promoter on a plasmid, expression of that gene can be induced by introduction of sub-inhibitory amounts of nisin (0.1-5.0 ng/ $\mathrm{ml}$ ). The most commonly used expression plasmid is pNZ8048 [15], which enables a gene insertion in the NcoI site overlapping the ATG start codon, allowing direct cloning of the gene fused to the nisA start codon [16]. Other commonly used strains and plasmids of the NICE system are reviewed in "10 years of NICE in L. lactis" [16]. Many of these $\mathrm{NICE}^{\circledR}$ plasmids and compatible host strains developed by NIZO Food Research (Netherlands) are now commercially available, with many derivatives being established using NIZO systems including a system for TA-cloning, designated pNZ-T to facilitate restriction enzyme independent cloning [17].

\section{Secretion strategies}

Secretion of heterologous proteins are mostly preferred compared to intracellularly expressed proteins due to advantages such as simpler purification steps, higher yields, and better target interactions [18]. In view of this, it is also advantageous to employ the secretion system when developing $L$. lactis as a host for heterologous protein production [19]. In addition, gram-positive bacteria have a monolayer cell wall that permits direct secretion into the extracellular environment in comparison to $E$. coli where secreted proteins are mostly stuck in the periplasm [20]. Furthermore, L. lactis only possesses a single extracellular housekeeping protease, HrtA, thereby reducing the chances of secreted heterologous proteins being degraded [21, 22]. 
Signal peptides (SPs) are N-terminal extensions of a protein which signals the host to target the protein towards the extracellular region by translocation across the cytoplasmic membrane and cell wall. While the sequence of SPs are vastly diversed, they display a common tripartite structure which includes the positively charged $\mathrm{N}$-terminus, the hydrophobic $\mathrm{H}$-region and the negatively charged cleavage region at the $\mathrm{C}$-terminus [23]. In L. lactis, there is only one majorly secreted protein which is Usp45, whose function is still unknown [19]. Nevertheless, the native lactococcal Usp45 SP is the most successful SP used thus far for secretion in L. lactis, and was recently engineered through a series of mutations to further increase its secretion efficiency (SE) by $51 \%$ [24]. More recently, we have isolated a novel signal peptide, SPK1 from Pediococcus pentasaceus, with the ability to secrete heterologous proteins with efficiencies comparable to Usp45 in L. lactis [25]. When SPK1 was used to secrete $\beta$-cyclodextrin glucanotransferase, although secretion efficiency was higher than USP45, total yield was found to be lower [26], thus demonstrating the complex effects brought upon by SPs, not only on the secretion of heterologous proteins, but on total protein yield as well.

Apart from SPs, past literature have reported several other strategies which have proven to improve SE in $L$. lactis including the use of synthetic LEISSTCDA propeptide sequence (SPs are followed by a propeptide sequence which is cleaved after translocation to produce the mature protein) [23], and the use of a hrtA mutant strains (the only reported cell surface proteolytic housekeeping gene) [22]. In another strategy, it was shown that the secretion yield of some heterologous proteins can be improved in L. lactis when co-expressed with B. subtilis PrsA protein, which is a surface anchored protein with chaperon-like functions and have been shown to decrease degradation of exported proteins [27].

\section{Surface display systems}

The thick and rigid cell wall of gram-positive bacteria as well as the lack of an outer membrane envelope has made them suitable for the cell surface display of proteins. Displaying proteins on bacterial cell wall allows the bacteria to act as carriers of proteins, especially antigens, and allow interaction of displayed proteins with targeted environments. There are five different types of protein anchors described in lactic acid bacteria; (1) transmembrane anchors: (2) lipoprotein anchors which binds to the cell membrane; (3) LPXTG-type cell wall anchoring domains; (4) AcmA-repeats anchor domain; (5) S-layer protein attachments which are bound to cell wall components [28].

In L. lactis, the most commonly used method for surface display of proteins is through the LPXTG sorting signal of surface-associated proteins which are recognized by the sortase enzyme, and covalently bound to the cell wall. In this method, the anchoring mechanism relies on the sortase activity as this membrane-anchored enzyme cleaves the sorting signal of the target protein at its pentapeptide motif (LPXTG) and promotes covalent anchoring of the target protein to the cell wall [29, 30]. However, non-covalent binding of cell surface proteins using lysin motifs (LysM) are also alternatively used, with the LysM of the autolysin AcmA being the most common [31]. More interestingly, non-covalent binding of antigens/proteins using AcmA has been shown to allow trans surface display, where proteins are displayed from the outside of L. lactis host cells, as we have previously shown [32]. Using this method, expression of heterologous proteins can be performed in a non-lactococcal host (e.g. E. coli), purified and bound non-covalently to the lactococcal cell wall simply by mixing the purified heterologous proteins to lactococcal cell cultures. More importantly, this enables the lactococcal cells to carry heterologous proteins without being genetically modified, a method which have also been demonstrated with Newcastle disease virus hemagglutinin-neuraminidase (HN) protein for specific targeting of breast cancer cells [33]. In addition, eukaryotic proteins which require post-translational modifications can also be expressed in eukaryotic hosts, and subsequently attached to L. lactis for delivery [34]. A variation of this method uses GEM (gram-positive enhancer matrix) particles which are killed non-recombinant lactococcal cells devoid of most intact cell wall components and intracellular materials. Antigens fused to streptococcal protein anchor enable them to be docked onto the peptidoglycan of GEM particles, which was also shown to elicit an immune response in nasally immunized mice [35]. A similar approach was also employed recently for subtilisin QK-2 using GEM [36]. The drawback of this system, however, is that the lactococcal cells are merely a carrier of the displayed protein, not a factory producing the proteins, thus repeated introduction of proteins displayed on lactococcal cells may be needed.

\section{Lactococcus lactis as a cell factory}

\section{Production of industrial metabolites and enzymes}

Naturally, L. lactis is a strictly homolactic fermentative bacteria which completely converts its carbon source into L-lactate from pyruvate through a very efficient lactate dehydrogenase (LDH) enzyme with a $K_{m}$ value of $1.1 \mathrm{mM}$ [37]. Lactic acid is an industrially important compound as it is used as an acidifier for preservation, as a flavour enhancing agent in the food industry [38], as an emulsifier and moisturizing agent in the cosmetic industry, and as an important raw material in the 
pharmaceutical industry [39]. Additionally, polymerization of lactic acid yields polylactic acid (PLA), which is a biodegradable thermoplastic polymer highly anticipated to potentially replace non-renewable oil based polymers [39]. While lactic acid remains the main product produced by $L$. lactis and other LAB, under different physiological conditions, three other enzymes apart from LDH also converts pyruvate: (i) $\alpha$-acetolactate synthase (ALS) which is active at high pyruvate concentrations and low $\mathrm{pH}(\leq 6.0)$ [40]; (ii) pyruvate-formate-lyase (PFL) which is active under anaerobic conditions and at relatively high $\mathrm{pH}$ of $>6.0$ [41]; and (iii) pyruvate dehydrogenase $(\mathrm{PDH})$ which is active under aerobic conditions and low $\mathrm{pH}(\leq 6.0)$ [42]. Therefore, L. lactis is also a natural factory for the production of many other aromatic acetylated products such as diacetyl, acetaldehyde and acetate, resulting from mixed fermentation. Nevertheless, LDH still dominates with maximal enzymatic activity at high sugar concentrations and high intracellular nicotinamide adenine dinucleotide dehydrogenase (NADH) levels [40, 43].

To date, metabolic engineering efforts in L. lactis have focussed primarily on customizing the prioritization of mixed fermentation products by re-routing lactatepyruvate metabolism towards other industrially important products such as diacetyl, acetaldehyde and acetoin which are important flavour compounds in dairy products. This was achieved through the use of an LDH deficient $L$. lactis strain which consequently increased the amount of $\alpha$-acetolactate in place of lactate, where the former is a reduced carboxylated form of diacetyl [40]. This together with other similar studies have indicated that LDH deficiency could result in $>80 \%$ of lactose being converted into other fermentation products other than lactic acid through overproduction of ALS and activation of the diacetyl-acetoin pathway for pyruvate metabolism [44].

Another common metabolic engineering strategy in $L$. lactis involves manipulation of the NADH:NAD ${ }^{+}$co-factor ratio which influences fermentation patterns because the in vivo activity of several central redox enzymes, namely glyceraldehyde 3-phosphate dehydrogenase (GADPH), PDH, LDH, alcohol dehydrogenase (ADH) and NADPH oxidase (NOX), are significantly influenced by this ratio. For example, the nox gene which encodes $\mathrm{NADH}$ oxidase converts molecular oxygen to water at the expense of NADH. Overexpression of NOX diminishes the NADH pool, and increases $\mathrm{NAD}^{+}$, thereby re-routing pyruvate from the NADH-dependent $\mathrm{LDH}$ pathway to either the NADH independent ALS pathway or the $\mathrm{NAD}^{+}$dependent PDH pathway. This strategy has been shown to be successful in shifting homolactic fermentation to mixed-acid fermentation with acetate and acetoin as main products, while producing $\alpha$-acetolactate and diacetyl in small amounts [45]. Combining this with disruption of the gene encoding $\alpha$-acetolactate decarboxylase also yielded high diacetyl production from glucose and lactose [46]. In fact, it was shown that the adjustment of aeration levels alone, even in minute amounts without any metabolic engineering was able to greatly re-route up to $80 \%$ of fermentation products from lactate to other products such as formate, acetate, and ethanol [47]. On a different note, $L$. lactis has also been engineered to be a factory for the production of sweeteners, including the introduction of heterologous pathways or enzymes such as alanine dehydrogenase from Bacillus sphaericus for the production of L-alanine [48].

More recently, the emphasis of metabolic engineering in L. lactis have somewhat shifted towards increasing the production of non-food flavouring metabolites. Examples include the B vitamins, primarily folate (B11) and riboflavin (B2), which were overexpressed in L. lactis using the NICE system [49-51]. These reports highlight L. lactis as a food-grade platform where the production of multivitamins from guanosine triphosphate (GTP) precursors can be increased by 3 to 10 folds following overexpression of a GTP biosynthetic enzyme (GTP cyclohydrolase I) [49, 50].

Other recent studies have shown the potential of $L$. lactis in bacteriocin production as a bio-preservative against Listeria monocytogenes [52, 53] and these bacteriocins have been found useful also for clinical applications [54] via prevention/reduction of biofilm formation. LAB bacteriocins are antimicrobial peptides which have been ribosomally synthesized at transcriptional and posttranscriptional levels; this confers auto-immunity to the producer strain [55]. Examples of more recent bacteriocins from L. lactis include lacticin 3147 [56], lacticin $\mathrm{Q} / \mathrm{Z}$ [57] and LsbB [58]. However, the most well-known and best characterised lantibiotic is nisin (term "lantibiotic" derived from Schnell [59] as lanthionine containing antibiotic), which had been discussed in depth in the preceding section. Current efforts are ongoing [60-62] to characterise bacteriocins from $L$. lactis and some favourable attributes for applications include acid stability and thermotolerance to high temperatures in addition to improvement in production systems.

On another note, L. lactis has also been engineered to produce ethanol as biofuels when supplemented with cheap renewable feedstock waste products [63]. A summary of industrial products produced on a lactococcal platform is summarized in Table 1.

\section{Production of therapeutics}

Due to its immunomodulatory properties and its ability to survive passage through the gastrointestinal tract 
Table 1 List of industrial enzymes and compounds produced from various Lactococcus lactis strains

\begin{tabular}{|c|c|c|c|}
\hline Industrial type \& products & Applications/functions & Lactococcus lactis strain & References \\
\hline \multicolumn{4}{|l|}{ Compounds } \\
\hline Lactic acid & $\begin{array}{l}\text { Preservative, flavouring, polylactic acid, plastic, } \\
\text { emulsifier, moisturizer }\end{array}$ & All strains & [43] \\
\hline Acetoin/diacetyl & Flavouring & CRL264 & [44] \\
\hline L-alanine & Sweetener & $\mathrm{AlaDH}^{+} \mathrm{LDH}^{-}$ & [48] \\
\hline Linalool & Flavouring & NZ9000 & [64] \\
\hline Germacrene D & Antimicrobial, insecticidal, pheromones & NZ9000 & [65] \\
\hline$\beta$-Sesquiphellandrene & Antimicrobial, antioxidant, anticancer & NZ9000 & {$[66,67]$} \\
\hline Hyaluronic acid & Cosmetics, medical & NZ9020 & \\
\hline \multicolumn{4}{|l|}{ Vitamins } \\
\hline Folate (B11) & Health supplements & NZ9000 & [49-51] \\
\hline Riboflavin (B12) & Health supplements & NZ9000 & \\
\hline \multicolumn{4}{|l|}{ Biofuels } \\
\hline Ethanol & Energy source & CS4435 & [63] \\
\hline \multicolumn{4}{|l|}{ Peptides } \\
\hline Bacteriocin & Anti-microbial, preservative & NZ9000 & {$[52,68]$} \\
\hline Brazzein & Sweetener & N/S & [69] \\
\hline Mabinlin II & Sweetener & $N / S$ & [70] \\
\hline Nisin Z & Food preservative & F44 & [71] \\
\hline \multicolumn{4}{|l|}{ Enzymes } \\
\hline$\beta$-Cyclodextrin glucanotransferase & Starch degradation & NZ9000 & [26] \\
\hline Coumarate CoA ligase (4CL) & Metabolic engineering & Fl9974 & [72] \\
\hline Alcohol acyltransferase (SAAT) & Metabolic engineering & NZ9000 & [64] \\
\hline Linalool/nerolidol synthase (FaNES) & Metabolic engineering & NZ9000 & [64] \\
\hline Sesquiterpene synthase & Metabolic engineering & NZ9000 & [65] \\
\hline $\begin{array}{l}\text { 3-Hydroxy-3-methylglutaryl CoA reductase } \\
\text { (HMGR) }\end{array}$ & Metabolic engineering & NZ9000 & [66] \\
\hline Bile salt hydrolase (BSH) & Intestinal metabolism, probiotics & NZ3900 & [73] \\
\hline Acid urease & Urea hydrolysis & N/S & [74] \\
\hline
\end{tabular}

N/S not specified

(GIT), yet not colonize the gut unlike Lactobacillus spp., L. lactis has been used as a vehicle to deliver therapeutics such as cytokines into the human body. The first evidence of such applications was published in Steidler et al. [75], where engineered secretion of interleukin-10 (IL-10) in L. lactis was used to treat inflammatory bowel disease (IBD) in colitis-induced mice. Since then, L. lactis secreting IL-10 has gone into clinical trials and concurrently ushered in the emergence of a genetically modified thymidine auxotrophic L. lactis strain for biological containment which disallows growth of the bacteria unless provided externally with thymidine or thymine $[76,77]$. While clinical trial results were not as promising as hoped, this bio-containment strategy was highly successful, making it a safe genetically modified organism (GMO) strain which addresses concerns relating to release to the public. Since the use of IL-10 for IBD treatment, many other therapeutics have been produced in $L$. lactis (Table 2) for the treatment of IBD including other cytokines, antioxidant enzymes and protease inhibitors [78].

When it comes to hypersensitivity, IL-10 secreting $L$. lactis strains have also been investigated as treatment against food allergy such as cow's milk allergy [79]. In this study involving $\beta$-lactoglobulin-induced anaphylaxis in mice, it was shown that oral administration of a recombinant $L$. lactis delivering IL-10 gastrointestinally prior to sensitization was able to induce immunotolerance towards the allergen, thus reducing food-induced anaphylaxis. Recombinant L. lactis producing IL-12, a T-helper 1 (Th1) bias cytokine has also been investigated for the treatment of asthma, successfully skewing the Th2 dominant immunologic response in murine models of asthma to a Th1 response which simultaneously elevates interferon gamma (IFN- $\gamma$ ) whilst reducing IL-4 levels [80]. To date, L. lactis has been used to co-produce or secrete a wide range of other adjuvants and growth factors. Successful examples include murine IL-12 [81], 
Table 2 Recombinant therapeutics produced from various Lactococcus lactis strains

\begin{tabular}{|c|c|c|c|}
\hline Therapeutic type $\&$ products & Disorder/disease & $\begin{array}{l}\text { Lactococcus lactis } \\
\text { strain }\end{array}$ & References \\
\hline \multicolumn{4}{|l|}{ Cytokines/ligands } \\
\hline Interleukin-6 (IL-6) & Adjuvant & IL1403 & [123] \\
\hline Interleukin-10 (IL-10) & $\begin{array}{l}\text { Adjuvant, hypersensitivity type l, inflammatory bowel } \\
\text { disease (IBD) }\end{array}$ & N/S & {$[75,79]$} \\
\hline Interleukin-12 (IL-12) & Adjuvant; hypersensitivity type l; asthma & NZ9000 & {$[75,79,81]$} \\
\hline Interleukin-18 (IL-18) & Adjuvant, immunomodulatory, & MG1363 & {$[124]$} \\
\hline Hemagglutinin-neuraminidase $(\mathrm{HN})$ protein of NDV & Breast cancer & NZ9000 & [33] \\
\hline RANKL & Cancer vaccine adjuvant & IL1403 & [84] \\
\hline Transforming growth factor beta 1 (TGF- $\beta 1$ ) & $\mathrm{IBD}$ & NZ9000 & [82] \\
\hline Epidermal growth factor (EGF) Trefoil factor 3 (TFF3) & Wound healing & NZ9000 & [125] \\
\hline Kisspeptin (KiSS 1) & Colorectal cancer & NZ9000 & [88] \\
\hline Insulin-like growth factor I (IGF-I) & Colitis & NZ9000 & [83] \\
\hline \multicolumn{4}{|l|}{ Allergens } \\
\hline Peanut allergen (Ara 2) & Hypersensitivity type I & CHW9 & [85] \\
\hline Birch allergen (Bet v1) & Hypersensitivity type I & NZ9800 & [86] \\
\hline House dust mite allergen (Der p2) & Hypersensitivity type I & NZ9000 & [87] \\
\hline \multicolumn{4}{|l|}{ Enzymes } \\
\hline Subtilisin QK-2 & Thrombosis & NZ9000 \& NZ3900 & {$[36]$} \\
\hline Heme oxygenase-1 (rmHO-1) & Acute colitis & NZ9000 & [126] \\
\hline \multicolumn{4}{|l|}{ Vaccines/antigens } \\
\hline Tetanus toxin fragment C (TTFC) & Tetanus & UCP1054 & {$[96,97]$} \\
\hline HPV-16-E7 & HPV-16 induced cancers & NZ9000 & {$[101,120]$} \\
\hline Pneumoccal antigen & Pneumococcal infections, meningitis & N/S & {$[35,104]$} \\
\hline Listeriolysin O \& mt Internalin A & Listeriosis & NZ9000 & [34] \\
\hline Glycosylated tyrosinase related protein-2 (TRP-2) & Skin cancer & MG1363 & [102] \\
\hline Carcinoembryonic antigen (CEA) & Colon cancer & NZ9000 & [127] \\
\hline $\begin{array}{l}\text { Plasmodium falciparum recombinant antigen } \\
\text { (R0.10C) }\end{array}$ & Malaria & $N / S$ & {$[105]$} \\
\hline Influenza virus nucleoprotein (NP) & Influenza & NZ9000 & [128] \\
\hline Shigella IpaB and IpaD & Shigellosis & PA1001 & {$[106-108]$} \\
\hline Neuraminidase (NA1) & Avian influenza H5N1 & NZ3000 & {$[109,110]$} \\
\hline Hemagglutinin (HA1) & Avian influenza $\mathrm{H} 5 \mathrm{~N} 1$ & NZ9000 & [111] \\
\hline Hemagglutinin (HA1) & Avian influenza H1N1 & NZ9000 & [112] \\
\hline M2e antigen & Avian influenza $\mathrm{H} 5 \mathrm{~N} 2$ & LM2301 & [113] \\
\hline IBV multi-epitope geneEpiC & Avian bronchitis & NZ3900 & [114] \\
\hline Campylobacter rCjaAD antigen & Avian gastroenteritis & |L1403 & [115] \\
\hline GroEL, heat-shock protein & Brucelosis & NZ9000 & [116] \\
\hline $\mathrm{Cu}$-Zn SOD of Brucella abortus & Brucelosis & NZ9000 & [129] \\
\hline Mycobacterial ESAT-6 antigen & Tubercolosis & N/S & [117] \\
\hline D1 and D4 aerolysin & Aeromonas spp. infection & Lac-D1ae & [118] \\
\hline SiMA antigen & Streptococcal infection & BFE920 & \\
\hline Myelin epitopes & Multiple sclerosis, encephalomyelitis & IBB360 & [130] \\
\hline T1D autoantigens & Type-1 diabetes mellitus & N/S & [131] \\
\hline $\begin{array}{l}\text { Enterohemorrhagic Escherichia coli (EHEC) antigen } \\
\text { (EspB) }\end{array}$ & EHEC infection & N/S & [132] \\
\hline Multi-urease epitopes (CTB-UE) & Helicobacter pylori infection & NZ9000 & [133] \\
\hline Helicobacter pylori hspA & Helicobacter pylori infection & NZ3900 & [71] \\
\hline HIV-1 Gag-p24 & Human immunodeficiency virus (HIV) infection & N/S & [134] \\
\hline Capsid protein of porcine circovirus type 2 (PCV2) & Swine circovirus associated disease & N/S & [135] \\
\hline
\end{tabular}


Table 2 continued

\begin{tabular}{|c|c|c|c|}
\hline Therapeutic type $\&$ products & Disorder/disease & $\begin{array}{l}\text { Lactococcus lactis } \\
\text { strain }\end{array}$ & References \\
\hline Staphylococcus aureus HtrA protease & Staphylococcal infection & IL1403 & [136] \\
\hline Staphylococcus aureus clumping factor A (CIfA) & Staphylococcal infection & N/S & [137] \\
\hline Hepatitis E virus antigen & Hepatitis E virus infection & NZ3900 & [138] \\
\hline Toxin A/B (TcdA/B) & Clostridium difficile infection & N/S & [139] \\
\hline F and G glycoproteins of Respiratory syncytial virus & Upper respiratory tract infection & NZ9000 & [140] \\
\hline \multicolumn{4}{|l|}{ Others } \\
\hline HSP65-6IA2P2 & Type 1 diabetes mellitus & NZ9000 & [90] \\
\hline Gamma-amino butyric acid (GABA) & Hypotensive, anti-cancer, anti-anxiety & All ssp. Lactis & [93] \\
\hline Bacillus thuringiensis crystal protein Cry5B & Anthelminthic & NCK203 & [89] \\
\hline Serine protease inhibitors & $\mathrm{IBD}$ & NZ9000 & {$[82]$} \\
\hline Glucagon like peptide-1 (GLP-1) & Type 2 diabetes mellitus & N/S & [141] \\
\hline
\end{tabular}

$N / S$ not specified

transforming growth factor beta 1 (TGF- $\beta 1$ ) [82], insulinlike growth factor I [83], receptor activator of nuclear factor kappa-B ligand (RANKL) [84] and others as detailed in Table 2.

Apart from the use of L. lactis in delivering cytokines to alleviate allergy symptoms, L. lactis has also been developed as factory for production and purification of the allergen itself. In 2007, Glenting et al. reported the production of immunologically active recombinant peanut allergen Ara 2 in L. lactis with high yields [85]. Recombinant allergens are arguably superior over natural allergen owing to its purity and batch to batch consistency. Furthermore, in addition to playing the role of factory in producing allergens, L. lactis can simultaneously be used to deliver allergens such as the major birch allergen Bet-v1 [86], and the house dust mite (HDM) allergen Der p2 [87] through the GIT to achieve immunotolerance prior to sensitization. L. lactis are naturally great delivery vehicles for allergy immunotherapy as many non-recombinant LAB by itself, including L. lactis, have shown anti-allergic effects through their immunomodulatory effects, owing to their cell wall components and other non-established factors.

Recently, in the field of anti-cancer therapeutics, recombinant $L$. lactis NZ9000 was used to secrete tumour metastasis-inhibiting peptides such as KiSS1 which inhibited HT-29 cell proliferation and migration through the induction of apoptosis pathways and by down regulating matrix metallopeptidase 9 (MMP-9) expression. This suggested a possible role for L. lactis as a cell factory for colorectal cancer therapeutics [88]. Other examples of therapeutics produced using L. lactis as a microbial cell factory include subtilisin QK-2 as an anti-thrombotic agent [36], BT crystal protein Cry5B as an anthelminthic [89], heat shock protein (hsp) 65-6IA2P2 against type 1 diabetes [90] and many others as summarized in Table 2.
In addition to protein- and whole cell-based therapeutics, metabolites with medicinal applications are also produced by $L$. lactis. An example is $\gamma$-amino butyric acid (GABA), which is a non-protein amino acid with hypotensive, anti-cancer, anti-anxiety and diuretic properties [91, 92]. Naturally produced GABA are generally favourable compared to its chemically synthesized counterpart, and also contributes to $\mathrm{pH}$ tolerance, hence making $\mathrm{LAB}$ excellent GABA producing candidates [93]. In $L$. lactis, GABA production can also be used to differentiate between L. lactis ssp. lactis and L. lactis ssp. cremoris as the former produces GABA while the latter does not [94]. Other examples of medicinal metabolites successfully synthesized by L. lactis includes hyaluronic acid, which is a carbohydrate polymer used in wound healing, dermatitis and cosmetic-based applications [67].

\section{Vaccine delivery system}

Without doubt, one of the most exciting aspects of modern L. lactis usage is as a factory for antigen production, thus allowing the bacteria to act as live vaccines. Using $\mathrm{LAB}$ as vaccine carriers is appealing as they are able to induce both mucosal and systemic immune responses, have adjuvant properties, and is free from risks associated with the use of conventional attenuated live pathogens such as Salmonella spp. and Mycobacterium spp. [95]. When it comes to vaccine design, the capability of L. lactis to surface display antigens also transforms it into the preferred host with increased immunogenicity compared to its intracellularly expressed or secreted counterparts [96]. One of the earliest pioneering vaccine initiatives using $L$. lactis involved expressing tetanus fragment toxin C (TFTC), which was highly successful in eliciting immune responses in mice, especially when administered together with IL-2 and IL-6 adjuvants [97]. Since then, a variety of antigens against both human 
and animal diseases have been expressed, secreted and surface displayed in L. lactis as detailed in several past reviews with a comprehensive list of LAB-based vaccines [98-100], together with an updated list as detailed in Table 2.

Over the past decade, the emergence of cancer vaccines developed via a lactococcal platform has also been gaining momentum following the onset of prokaryotic antigen production. These include a vaccine against human papilloma virus type-16 induced tumours where L. lactis surface displaying the E7 antigen whist secreting IL-12 was shown to provide full prophylactic protection in immunized mice and was also able to induce regression of palpable tumours in tumour-induced mice [101]. Other cancer antigens expressed using $L$. lactis includes glycosylated tyrosinase related protein-2 (TRP-2) tumour antigen against melanoma (although this has not gone to animal trials) [34] and carcinoembryonic antigen (CEA) against colon cancer in mice [102]. The latter showed successful induction of immune response in mice as indicated by higher levels of CEA-specific secretory IgA compared to controls.

Being capable of heterologous protein expression, characterization of bacterial and viral virulence factors using L. lactis was also made possible without the pathogen's clinical manifestations. A very recent example is the expressive characterization of the Streptococcus mutans surface glycoprotein, $\mathrm{Cnm}$ in L. lactis which was found to mediate binding to extracellular matrix (ECM) proteins in a rabbit model of infective endocarditis [103]. In addition, virulence factors comprising mutated internalin A and listeriolysin O (LLO) from food-borne pathogen $L$. monocytogenes have been proposed for use in DNA vaccination using L. lactis as hosts for plasmid production [104]. Recombinant L. lactis strains harbouring viral antigens such as influenza A nucleoprotein (NP) have also been studied, and shown to elicit superior immunogenicity, especially when coupled with oral adjuvants such as cholera toxin B (CTB) subunits [105].

Various lactococcal-based vaccines for animal diseases have also been developed, mostly with favourable results. In poultry diseases, extensive research has been performed against the $\mathrm{H} 5 \mathrm{~N} 1$ virus, using L. lactis as a vaccine delivery system via oral and intranasal administration routes in chickens and ferrets [106-109]. It was demonstrated that these lactococcal vaccines were able to induce high hemagglutinin A (HA)-specific serum IgG and fecal IgA, with the secreted form being more efficient than the intracellularly expressed vaccine [109]. Following this, surface display of HA antigen onto L. lactis surface using PgsA anchor motif administered orally together with (CTB) as adjuvant was also found to elicit high antigen-specific cell-mediated responses in mice when challenged with lethal dosages of H5N1 [110]. This demonstrated the stability and immunogenicity of surface anchored proteins as per many previous studies. Other lactococcal based vaccines developed or under development for the poultry industry include those against H1N1 [111], H5N2 [112], avian infectious bronchitis virus [113] and infections by Campylobacter jejuni [114].

One of the earliest uses of $L$. lactis in the livestock industry was reported a decade ago, where GroEL heat shock protein from Brucella abortus was expressed and secreted as a vaccine candidate. However, its intracellular expression was shown to be unstable with a low secretion efficiency [115]. Through technological advancements in expression and secretion systems, consecutive attempts were proven more successful when oral administration of recombinant lactococcal strains secreting $\mathrm{Cu}-\mathrm{Zn}$ superoxide dismutase (SOD) of $B$. abortus was found to render protective immunity against brucellosis when tested in mice [116]. Very recently, oral administration of recombinant insulin-like growth factor I (IGF-I) expressed in L. lactis also reported good biological activity, where symptoms and development of dextran sodium sulphate (DSS)-induced colitis in mice were attenuated [83]. Use of L. lactis has also made hallmarks in the aquaculture industry where lactococcalbased vaccines against Aeromonas hydrophila using D1 and D4 aerolysin genes were developed with increased survival in tilapia fish when administered intraperitoneally and orally [117]. Lactococcal expression of the SiMA antigen, a Streptococcus iniae membrane protein, has also incurred significant vaccinative and probiotic effects in olive flounders [118].

At present, enhancements to the lactococcal vaccine delivery system are continuously being carried out, amongst which, includes the recent incorporation of the cell-surface anchored fibronectin binding protein A (FnBPA) from Staphylococcus aureus which functions to increase immunomodulatory properties of $L$. lactis strains during mucosal delivery as a live DNA vaccine vector $[119,120]$. L. lactis shuttle vectors such as the pNZ:vig [121] and pPERDBY reporter plasmid [122] for the delivery of DNA vaccines to mammalian cells have also been developed and in the latter shown to perform efficiently in the absence of invasive proteins or relevant chemical treatments. As an effort to provide protection against gastric digestion, enteric coated encapsulation of lactococcal vaccines have also been explored with superior levels of antibodies being elicited, conferring full protection against $\mathrm{H} 5 \mathrm{~N} 1$ in mice [109]. It is apparent from Table 2 that the use of L. lactis as a factory for antigens and adjuvants renders it a very promising live bacterial vaccine host, 
consequently turning it into one of the most extensively researched areas.

\section{Production of heterologous plant-based proteins}

Although unconventional, L. lactis has also been engineered as a cell factory for the production of both plant proteins and bioactive compounds as described in Table 1. Coumarate CoA ligase (4CL) from Arabidopsis thaliana was the first functional plant protein to be expressed in L. lactis [72]. A year later, brazzein, a sweet tasting plant protein, extracted from the fruit of the West African plant, Pentadiplandra brazzeana, was successfully expressed, albeit in low amounts [142]. The establishment of plant protein expression in L. lactis soon led to the metabolic engineering and consequent production of industrially applicable secondary metabolites. In 2007, alcohol acyltransferase (SAAT) and linalool/nerolidol synthase (FaNES) of strawberry were reportedly expressed in L. lactis, leading to the production of the flavouring and scent compound, linalool [64], which is used in various essential oil-containing cosmetics and fragrances.

Our research group has also successfully expressed two plant terpene synthases from orchid [65] and kesum (Persicaria minor) [66] in L. lactis leading to the production of germacrene $D$ and $\beta$-sesquiphellandrene, respectively. Interestingly, L. lactis uses the mevalonate pathway (MVA) for terpenoid biosynthesis, a pathway more commonly found in eukaryotes. Most prokaryotes such as E. coli uses another terpenoid biosynthesis pathway called the 2-C-methyl-D-erythritol-4-phosphate (MEP) pathway, hence almost all metabolic engineering research for heterologous plant terpenoid production have been focussed on the MEP pathway of E. coli or the MVA pathway of yeast. At present, the lactococcal MVA accommodates much room for optimization as initial attempts to metabolically engineer this pathway resulted in more than doubling of sesquiterpenes produced [143].

\section{Production of membrane-based proteins}

Membrane proteins are typically difficult proteins to express and purify due to their nature which includes low abundance, relatively high hydrophobicity, instability and various topologies including polytopic proteins with multiple transmembrane regions. Due to these limitations, only about 400 three-dimensional membrane protein structures have been elucidated compared to 40,000 soluble proteins, which accounts for a mere $0.01 \%$ [144]. Over the past two decades, L. lactis has been proven to be an excellent host for the expression of membrane proteins due to several advantages: (i) they are amino acid auxotrophs allowing incorporation of labels for detection, (ii) they only have a single membrane layer compared to E. coli, (iii) they have a small genome size with little proteolytic activity, and (iv) they come with extensive genetic engineering tools including the highly efficient and well tested NICE system.

To date, there are close to 100 membrane proteins expressed in L. lactis using the NICE system alone, including both prokaryotic and eukaryotic membrane proteins [144]. Kunji and colleagues [145] were the pioneers in using L. lactis as an alternative host for membrane protein overexpression of eukaryotic expression, successfully expressing human Lys-Asp-Glu-Leu KDEL receptor and mitochondrial carriers from yeasts and fungi. Prior to this, only prokaryotic membrane protein expressions were performed in L. lactis, mostly with homologous proteins, some which were able to reach up to $30 \%$ of total membrane proteins [144]. Most recently, L. lactis was successfully used to express rat and human membrane proteins involved in liver detoxification with higher yields than conventional E. coli and Saccharomyces cerevisiae expression systems [146].

Lactococcus lactis has also been developed as an alternative system for the production of plant membrane proteins, using $A$. thaliana peripheral and intrinsic proteins as a model [147]. A lactococcal cloning strategy compatible to Gateway entry vectors were established where available Gateway-based $A$. thaliana cDNA libraries were cloned into Gateway entry vectors and transferred into a destination vector (pBS-RFA) through recombination, thus allowing for proper reading frame preservation. The gene of interest is then excised and cloned into pNZ8148 and expressed as usual using the NICE system. This method allows for the use of Gateway available cDNA libraries, which in essence, cannot be used with the lactococcal NICE system due to host incompatibility. Using this method, six $A$. thaliana membrane proteins were produced of which three were successfully solubilized and purified with two of them being shown to be functional [147].

Using modified Gateway-compatible systems, research efforts were extended to the expression of 20 different membrane proteins from plants, human and bacteria in six different hosts including L. lactis, where Lactococcal-based expression was found to be an efficient and valuable alternative to $E$. coli, many times complementing proteins which were unsuccessfully produced in the latter [148]. While E. coli remains the superior host in terms of production yield in most cases, the fusion of proteins with Mistic, a $13 \mathrm{kDa}$ protein from $B$. subtilis was reported to facilitate and improve membrane protein production in $L$. lactis. A more recent research validated the use of Mistic in successfully boosting the expression 
of both eukaryotic and prokaryotic membrane protein expression in L. lactis [149].

\section{Challenges and future prospects}

While manipulations involving L. lactis enables various heterologous genes to be expressed, its yield is very much case-dependant, with lesser problems when it comes to closely related organisms such as Streptococcus spp., Enterococcus spp., Staphylococcus spp. and low-GC Lactobacillus spp. However, the greatest obstacle still revolves around its codon usage and/or distribution of rarely used codons $[16,150]$. Additionally, gram protein per litre secretion in the microaerophilic Lactococcus spp. is still generally less robust when compared to the aerobically growing $B$. subtilis. Previously, genes encoding toxic gene products typically resulted in unsuccessful cloning attempts, further challenging the already-low transformation rate, but this was overcome by incorporating the nisA promoter in single copy on the chromosome $[151,152]$.

Following up on the use of NICE system, controlling the consistency of dosages and delivery of therapeutic molecules is also difficult to predict with L. lactis owing to the loosely controlled stability and small intestinal absorption of nisin, which ultimately influences the pharmacokinetics and pharmacodynamics interplay [69]. Another challenge involves the fine balance between switching from homolactic to mixed-acid fermentation in L. lactis which remains unresolved to-date [153], and elucidating this may vastly improve the potential of $L$. lactis as a cell factory.

In spite of limited systematic studies available on the acquired antibiotic resistance especially from food due to L. lactis designated GRAS status, a study documenting multiple drug efflux proteins attributing resistance to ethidium bromide was discovered in L. lactis subsp. lactis MG1363 [154]. Since much of the use for L. lactis as a cell factory involves ingestion or uptake into the host, there lies a risk for horizontal transfer of these efflux pumps to other commensal or potentially pathogenic bacteria. In other words, transit of L. lactis through the GIT which is frequently exposed to antibiotics may cause susceptible gene exchange with the surrounding flora, potentially leading to antibiotic resistant strains. In addition, release of chloramphenicol resistant pNZ-harbouring L. lactis strains into the environment is also a grave concern.

Therefore, it is imperative that guidelines mandating the management of $L$. lactis as a cell factory be put in place, especially for new strains, that conform to premarketing safety profiling and post-marketing follow-up to determine their acceptability [155]. Many lactococcal system developments have also incorporated food-grade markers in place of antibiotic resistance markers so as to maintain the GRAS status of L. lactis [156]. Alternatively, much consideration should be given on privileged aspects whereby recombinant $L$. lactis should be used. Examples include basis of delivered molecule, persistence of strain, robustness of the expression system, composition of different molecule subtypes and delivery to specific eukaryotic cells [157]. While its long history and safe use may be somewhat arguable, oftentimes, modifications to the final engineered product may bring about unexpected consequences [158], which also explains why only a few cell factories involving $L$. lactis have actually entered human trials.

When it comes to cancer vaccines, new knowledge and advancements in immunomodulation and microencapsulation technology of live lactococcal delivery vectors coupled with the richness of gut-associated lymphoid tissues (GALTs) have consequently opened up a gateway in exploiting future vaccination efforts via an oral-mucosal route, where we predict future research efforts being streamlined towards the lactococcal-based production of recombinant tumour antigens, especially against gastrointestinal malignancies over the next decade. In essence, this approach slingshots the practical use of peptidebased vaccines by overcoming its existing shortcomings such as its poor plasma stability and systemic half-life when administered in vivo.

\section{Conclusions}

Lactococcus lactis have come a long way from being a food bacterium to a microbial cell factory for the production of industrially important products with potentially great bio-economic value, especially in the medical field. In spite of its limitations, there is still much room for improvement of the lactococcal system as a microbial cell factory since its molecular toolbox is still relatively limited compared to those available for E. coli. An expansion of said toolbox would be akin to opening a Pandora's box, thus allowing further potential especially in terms of genetic and metabolic engineering to overcome limitations highlighted above.

\section{Abbreviations}

MEP: 2-C-methyl-D-erythritol-4-phosphate; 4CL: 4-coumarate-CoA ligase; ADH: alcohol dehydrogenase; ALS: al pha-acetolactate synthase; CEA: carcinoembryonic antigen; CTB: cholera toxin B; DSS: dextran sulfate sodium; EHEC: enterohemorrhagic Escherichia coli; ECM: extracellular matrix; FnbpA: fibronectinbinding protein A; FDA: Food and Drug Administration; GABA: gamma-amino butyric acid; GIT: gastrointestinal tract; GMO: genetically modified organism; GEM: gram-positive extracellular matrix; GRAS: generally regarded as safe; GAPDH: glyceraldehyde 3-phosphate dehydrogenase; GTP: guanosine triphosphate; GALT: gut-associated lymphoid tissue; Hsp: heat shock protein; HA: hemagglutinin; HN: hemagglutinin-neuraminidase; HIV: human immunodeficiency virus; IBV: infectious bronchitis virus; IBD: inflammatory bowel disease; IGF-I: insulin-like growth factor I; IFN: interferon; IL: interleukin; KDEL: Lys-AspGlu-Leu; KRAS: Kirsten rat sarcoma viral oncogene homolog; LDH: lactate dehydrogenase; LAB: lactic acid bacteria; LLO: listeriolysin O; LysM: Iysine motif; 
MVA: mevalonate pathway; NOX: NADPH oxidase; NDV: Newcastle disease virus; NADH: nicotinamide adenine dinucleotide dehydrogenase; NICE: nisin-controlled gene expression; NP: nucleoprotein; PLA: polylactic acid; PCV: porcine circovirus; PDH: pyruvate dehydrogenase; PFL: pyruvate-formate-lyase: SE: secretion efficiency; SP: signal peptides; SOD: superoxide dismutase; Th: T-helper; TGF- $\beta 1$ : transforming growth factor beta 1;T1D: type-1 diabetes.

\section{Authors' contributions}

AAS contributed to the review on cloning and expression systems, LILA contributed to the review on therapeutic and vaccine products, LSHE contributed to the review on industrial products and compounds, while RAR provided insights on challenges and future prospects of L. lactis. All authors read and approved the final manuscript.

\section{Author details}

1 Department of Microbiology, Faculty of Biotechnology \& Biomolecular Sciences, University Putra Malaysia, 43400 Serdang, Selangor, Malaysia. ${ }^{2}$ Functional Food Research Group, Department of Biotechnology, Faculty of Applied Sciences, UCSI University, Kuala Lumpur, Malaysia. ${ }^{3}$ Perdana University-Royal College of Surgeons in Ireland, Perdana University, Block B and D, MAEPS Building, MARDI Complex, Jalan MAEPS Perdana, 43400 Serdang, Selangor, Malaysia. ${ }^{4}$ Department of Cell \& Molecular Biology, Faculty of Biotechnology \& Biomolecular Sciences, University Putra Malaysia, Serdang, Selangor, Malaysia.

\section{Acknowledgements}

Not applicable.

\section{Competing interests}

The authors declare that they have no competing interests.

\section{Availability of data and materials}

The datasets supporting the review are included within the article.

\section{Funding}

This study was supported by a grant from the Ministry of Higher Education (MOHE) through the Fundamental Research Grant Scheme (FRGS/1/2014/ SG05/UCSI/03/1) and the Ministry of Science Technology and Innovation (MOSTI) (02-02-22-SF0011).

\section{Publisher's Note}

Springer Nature remains neutral with regard to jurisdictional claims in published maps and institutional affiliations.

Received: 13 November 2016 Accepted: 28 March 2017 Published online: 04 April 2017

\section{References}

1. Bolotin A, Wincker P, Mauger S, Jaillon O, Malarme K, Weissenbach J, Ehrlich SD, Sorokin A. The complete genome sequence of the lactic acid bacterium Lactococcus lactis ssp. lactis IL1403. Genome Res. 2001;11:731-53.

2. Parapouli M, Delbes-Paus C, Kakouri A, Koukkou Al, Montel MC, Samelis J. Characterization of a wild, novel nisin a-producing Lactococcus strain with an L. lactis subsp. cremoris genotype and an L. lactis subsp. lactis phenotype, isolated from Greek raw milk. Appl Environ Microbiol. 2013;79:3476-84.

3. Duwat P, Sourice S, Cesselin B, Lamberet G, Vido K, Gaudu P, Le Loir Y, Violet F, Loubiere P, Gruss A. Respiration capacity of the fermenting bacterium Lactococcus lactis and its positive effects on growth and survival. J Bacteriol. 2001;183:4509-16.

4. Garrigues C, Loubiere P, Lindley ND, Cocaign-Bousquet M. Control of the shift from homolactic acid to mixed-acid fermentation in Lactococcus lactis: predominant role of the NADH/NAD+ ratio. J Bacteriol. 1997;179:5282-7.

5. Garcia-Fruitos E. Lactic acid bacteria: a promising alternative for recombinant protein production. Microb Cell Fact. 2012:11:157.
6. Linares DM, Kok J, Poolman B. Genome sequences of Lactococcus lactis MG1363 (revised) and NZ9000 and comparative physiological studies. J Bacteriol. 2010;192:5805-12.

7. D'Souza R, Pandeya D, Hong S. Review: Lactococcus lactis: an efficient Gram positive cell factory for the production and secretion of recombinant protein. Biomed Res. 2012;23:1-7.

8. Maidin MS, Song AA, Jalilsood T, Sieo CC, Yusoff K, Rahim RA. Construction of a novel inducible expression vector for Lactococcus lactis M4 and Lactobacillus plantarum Pa21. Plasmid. 2014;74:32-8.

9. Zhu D, Liu F, Xu H, Bai Y, Zhang X, Saris PE, Qiao M. Isolation of strong constitutive promoters from Lactococcus lactis subsp. lactis N8. FEMS Microbiol Lett. 2015;362:fnv107.

10. Llull D, Poquet I. New expression system tightly controlled by zinc availability in Lactococcus lactis. Appl Environ Microbiol. 2004;70:5398-406.

11. Madsen SM, Arnau J, Vrang A, Givskov M, Israelsen H. Molecular characterization of the $\mathrm{pH}$-inducible and growth phase-dependent promoter P170 of Lactococcus lactis. Mol Microbiol. 1999;32:75-87.

12. Mu D, Montalban-Lopez M, Masuda Y, Kuipers OP. Zirex: a novel zinc-regulated expression system for Lactococcus lactis. Appl Environ Microbiol. 2013;79:4503-8.

13. Miyoshi A, Jamet E, Commissaire J, Renault P, Langella P, Azevedo V. A xylose-inducible expression system for Lactococcus lactis. FEMS Microbiol Lett. 2004;239:205-12.

14. Kuipers OP, Beerthuyzen MM, de Ruyter PG, Luesink EJ, de Vos WM. Autoregulation of nisin biosynthesis in Lactococcus lactis by signal transduction. J Biol Chem. 1995;270:27299-304.

15. Kuipers $O$, de Ruyter P, Kleerebezem M, de Vos W. Quorum sensingcontrolled gene expression in lactic acid bacteria. J Biotechnol. 1998:64:15-21.

16. Mierau I, Kleerebezem M. 10 years of the nisin-controlled gene expression system (NICE) in Lactococcus lactis. Appl Microbiol Biotechnol. 2005;68:705-17.

17. Berlec A, Strukelj B. Generating a custom TA-cloning expression plasmid for Lactococcus lactis. Biotechniques. 2012;52:51-3.

18. Le Loir Y, Azevedo V, Oliveira SC, Freitas DA, Miyoshi A, BermudezHumaran LG, Nouaille S, Ribeiro LA, Leclercq S, Gabriel JE, et al. Protein secretion in Lactococcus lactis: an efficient way to increase the overall heterologous protein production. Microb Cell Fact. 2005;4:2.

19. Morello E, Bermudez-Humaran LG, Llull D, Sole V, Miraglio N, Langella P, Poquet I. Lactococcus lactis, an efficient cell factory for recombinant protein production and secretion. J Mol Microbiol Biotechnol. 2008:14:48-58.

20. Schneewind O, Missiakas DM. Protein secretion and surface display in gram-positive bacteria. Philos Trans R Soc Lond B Biol Sci. 2012;367:1123-39.

21. Sriraman K, Jayaraman G. HtrA is essential for efficient secretion of recombinant proteins by Lactococcus lactis. Appl Environ Microbiol. 2008:74:7442-6.

22. Poquet I, Saint V, Seznec E, Simoes N, Bolotin A, Gruss A. HtrA is the unique surface housekeeping protease in Lactococcus lactis and is required for natural protein processing. Mol Microbiol. 2000;35:1042-51.

23. Le Loir Y, Nouaille S, Commisaire J, Brétigny L, Gruss A, Langella P. Signal peptide and propeptide optimization for heterologous protein secretion in Lactococcus lactis. Appl Environ Microbiol. 2001;67:4119-27.

24. Ng DT, Sarkar CA. Engineering signal peptides for enhanced protein secretion from Lactococcus lactis. Appl Environ Microbiol. 2013:79:347-56.

25. Baradaran A, Sieo CC, Foo HL, Illias RM, Yusoff K, Rahim RA. Cloning and in silico characterization of two signal peptides from Pediococcus pentosaceus and their function for the secretion of heterologous protein in Lactococcus lactis. Biotechnol Lett. 2013;35:235-8.

26. Subramaniam M, Baradaran A, Rosli MI, Rosfarizan M, Khatijah Y, Raha AR. Effect of signal peptides on the secretion of beta-cyclodextrin glucanotransferase in Lactococcus lactis NZ9000. J Mol Microbiol Biotechnol. 2012;22:361-72.

27. Lindholm A, Ellmen U, Tolonen-Martikainen M, Palva A. Heterologous protein secretion in Lactococcus lactis is enhanced by the Bacillus subtilis chaperone-like protein PrsA. Appl Microbiol and Biotechnol. 2006;73:904-14.

28. Leenhouts K, Buist G, Kok J. Anchoring of proteins to lactic acid bacteria. Antonie Van Leeuwenhoek. 1999;76:367-76. 
29. Mazmanian SK, Liu G, Ton-That H, Schneewind O. Staphylococcus aureus sortase, an enzyme that anchors surface proteins to the cell wall. Science. 1999;285:760-3.

30. Navarre WW, Schneewind O. Proteolytic cleavage and cell wall anchoring at the LPXTG motif of surface proteins in gram-positive bacteria. Mol Microbiol. 1994;14:115-21.

31. Berlec A, Zadravec P, Jevnikar Z, Strukelj B. Identification of candidate carrier proteins for surface display on Lactococcus lactis by theoretical and experimental analyses of the surface proteome. Appl Environ Microbiol. 2011;77:1292-300.

32. Raha AR, Varma NR, Yusoff K, Ross E, Foo HL. Cell surface display system for Lactococcus lactis: a novel development for oral vaccine. Appl Microbiol Biotechnol. 2005;68:75-81.

33. Baradaran A, Yusoff K, Shafee N, Rahim RA. Newcastle disease virus hemagglutinin neuraminidase as a potential cancer targeting agent. J Cancer. 2016;7:462-6.

34. Kalyanasundram J, Chia SL, Song AA, Raha AR, Young HA, Yusoff K. Surface display of glycosylated Tyrosinase related protein-2 (TRP-2) tumour antigen on Lactococcus lactis. BMC Biotechnol. 2015;15:113.

35. Audouy SA, van Roosmalen ML, Neef J, Kanninga R, Post E, van Deemter M, Metselaar H, van Selm S, Robillard GT, Leenhouts KJ, Hermans PW. Lactococcus lactis GEM particles displaying pneumococcal antigens induce local and systemic immune responses following intranasal immunization. Vaccine. 2006;24:5434-41.

36. Mao R, Zhou K, Han Z, Wang Y. Subtilisin QK-2: secretory expression in Lactococcus lactis and surface display onto gram-positive enhancer matrix (GEM) particles. Microb Cell Fact. 2016;15:80.

37. Hols P, Kleerebezem M, Schanck AN, Ferain T, Hugenholtz J, Delcour J, de Vos WM. Conversion of Lactococcus lactis from homolactic to homoalanine fermentation through metabolic engineering. Nat Biotechnol. 1999:17:588-92.

38. Smit G, Smit BA, Engels WJ. Flavour formation by lactic acid bacteria and biochemical flavour profiling of cheese products. FEMS Microbiol Rev. 2005;29:591-610.

39. Papagianni M. Metabolic engineering of lactic acid bacteria for the production of industrially important compounds. Comput Struct Biotechnol J. 2012;3:e201210003.

40. Platteeuw C, Hugenholtz J, Starrenburg M, van Alen-Boerrigter I, de Vos WM. Metabolic engineering of Lactococcus lactis: influence of the overproduction of alpha-acetolactate synthase in strains deficient in lactate dehydrogenase as a function of culture conditions. Appl Environ Microbiol. 1995;61:3967-71.

41. Abbe K, Takahashi S, Yamada T. Involvement of oxygen-sensitive pyruvate formate-lyase in mixed-acid fermentation by Streptococcus mutans under strictly anaerobic conditions. J Bacteriol. 1982;152:175-82.

42. Snoep JL, Teixeira de Mattos MJ, Starrenburg MJ, Hugenholtz J. Isolation, characterization, and physiological role of the pyruvate dehydrogenase complex and alpha-acetolactate synthase of Lactococcus lactis subsp. lactis bv. diacetylactis. J Bacteriol. 1992;174:4838-41.

43. Kandler O. Carbohydrate metabolism in lactic acid bacteria. Antonie Van Leeuwenhoek. 1983;49:209-24.

44. Garcia-Quintans N, Repizo G, Martin M, Magni C, Lopez P. Activation of the diacetyl/acetoin pathway in Lactococcus lactis subsp. lactis bv. diacetylactis CRL264 by acidic growth. Appl Environ Microbiol. 2008;74:1988-96.

45. de Felipe FL, Kleerebezem M, de Vos W, Hugenholtz J. Cofactor engineering: a novel approach to metabolic engineering in Lactococcus lactis by controlled expression of NADH oxidase. J Bacteriol. 1998;180:3804-8.

46. Hugenholtz J, Looijesteijn E, Starrenburg M, Dijkema C. Analysis of sugar metabolism in an EPS producing Lactococcus lactis by 31P NMR. J Biotechnol. 2000;77:17-23.

47. Andersen HW, Pedersen MB, Hammer K, Jensen PR. Lactate dehydrogenase has no control on lactate production but has a strong negative control on formate production in Lactococcus lactis. Eur J Biochem. 2001;268:6379-89.

48. Hols P, Ramos A, Hugenholtz J, Delcour J, de Vos WM, Santos H, Kleerebezem M. Acetate utilization in Lactococcus lactis deficient in lactate dehydrogenase: a rescue pathway for maintaining redox balance. J Bacteriol. 1999;181:5521-6.
49. Sybesma W, Burgess C, Starrenburg M, van Sinderen D, Hugenholtz J. Multivitamin production in Lactococcus lactis using metabolic engineering. Metab Eng. 2004;6:109-15.

50. Sybesma W, Starrenburg M, Kleerebezem M, Mierau I, de Vos WM, Hugenholtz J. Increased production of folate by metabolic engineering of Lactococcus lactis. Appl Environ Microbiol. 2003;69:3069-76.

51. Sybesma W, Van Den Born E, Starrenburg M, Mierau I, Kleerebezem M, De Vos WM, Hugenholtz J. Controlled modulation of folate polyglutamyl tail length by metabolic engineering of Lactococcus lactis. Appl Environ Microbiol. 2003;69:7101-7.

52. Unlu G, Nielsen B, Ionita C. Inhibition of Listeria monocytogenes in hot dogs by surface application of freeze-dried bacteriocin-containing powders from lactic acid bacteria. Probiot Antimicrob Proteins. 2016;8:102-10.

53. Bolocan AS, Pennone V, O'Connor PM, Coffey A, Nicolau AI, McAuliffe O, Jordan K. Inhibition of Listeria monocytogenes biofilms by bacteriocinproducing bacteria isolated from mushroom substrate. J Appl Microbiol. 2017;122:279-93.

54. Cirkovic I, Bozic DD, Draganic V, Lozo J, Beric T, Kojic M, Arsic B, Garalejic E, Djukic S, Stankovic S. Licheniocin 50.2 and bacteriocins from Lactococcus lactis subsp. lactis biovar. diacetylactis BGBU1-4 Inhibit biofilms of coagulase negative staphylococci and Listeria monocytogenes clinical isolates. PLoS ONE. 2016;11:e0167995.

55. Alkhatib Z, Abts A, Mavaro A, Schmitt L, Smits SH. Lantibiotics: how do producers become self-protected? J Biotechnol. 2012;159:145-54.

56. McAuliffe O, Ryan MP, Ross RP, Hill C, Breeuwer P, Abee T. Lacticin 3147 , a broad-spectrum bacteriocin which selectively dissipates the membrane potential. Appl Environ Microbiol. 1998;64:439-45.

57. Iwatani S, Ishibashi N, Flores FP, Zendo T, Nakayama J, Sonomoto K. LnqR, a TetR-family transcriptional regulator, positively regulates lacticin Q production in Lactococcus lactis QU 5. FEMS Microbiol Lett. 2016;363:fnw200.

58. Miljkovic M, Uzelac G, Mirkovic N, Devescovi G, Diep DB, Venturi V, Kojic M. LsbB bacteriocin interacts with the third transmembrane domain of the YviB receptor. Appl Environ Microbiol. 2016;82:5364-74.

59. Schnell N, Entian KD, Schneider U, Gotz F, Zahner H, Kellner R, Jung G. Prepeptide sequence of epidermin, a ribosomally synthesized antibiotic with four sulphide-rings. Nature. 1988;333:276-8.

60. Bodaszewska-Lubas M, Brzychczy-Wloch M, Gosiewski T, Heczko PB. Antibacterial activity of selected standard strains of lactic acid bacteria producing bacteriocins-pilot study. Postepy Hig Med Dosw. 2012;66:787-94.

61. Zhou XX, Li WF, Ma GX, Pan YJ. The nisin-controlled gene expression system: construction, application and improvements. Biotechnol Adv. 2006;24:285-95.

62. Hernandez-Saldana OF, Valencia-Posadas M, de la Fuente-Salcido NM Bideshi DK, Barboza-Corona JE. Bacteriocinogenic bacteria isolated from raw goat milk and goat cheese produced in the center of Mexico. Indian J Microbiol. 2016;56:301-8.

63. Liu J, Dantoft SH, Wurtz A, Jensen PR, Solem C. A novel cell factory for efficient production of ethanol from dairy waste. Biotechnol Biofuels. 2016;9:33.

64. Hernandez I, Molenaar D, Beekwilder J, Bouwmeester H, van Hylckama Vlieg JE. Expression of plant flavor genes in Lactococcus lactis. Appl Environ Microbiol. 2007;73:1544-52.

65. Song AA, Abdullah JO, Abdullah MP, Shafee N, Rahim RA. Functional expression of an orchid fragrance gene in Lactococcus lactis. Int J Mol Sci. 2012;13:1582-97.

66. Song AA, Abdullah JO, Abdullah MP, Shafee N, Othman R, Tan EF, Noor NM, Raha AR. Overexpressing 3-hydroxy-3-methylglutaryl coenzyme A reductase (HMGR) in the lactococcal mevalonate pathway for heterologous plant sesquiterpene production. PLoS ONE. 2012;7:e52444.

67. Rajendran V, Puvendran K, Guru BR, Jayaraman G. Design of aqueous two-phase systems for purification of hyaluronic acid produced by metabolically engineered Lactococcus lactis. J Sep Sci. 2016;39:655-62.

68. Geldart K, Borrero J, Kaznessis YN. Chloride-inducible expression vector for delivery of antimicrobial peptides targeting antibiotic-resistant Enterococcus faecium. Appl Environ Microbiol. 2015;81:3889-97.

69. Berlec A, Ravnikar M, Strukelj B. Lactic acid bacteria as oral delivery systems for biomolecules. Pharmazie. 2012;67:891-8. 
70. Gu W, Xia Q, Yao J, Fu S, Guo J, Hu X. Recombinant expressions of sweet plant protein mabinlin II in Escherichia coli and food-grade Lactococcus lactis. World J Microbiol Biotechnol. 2015;31:557-67.

71. Zhang XJ, Feng SY, Li ZT, Feng YM. Expression of Helicobacter pylori hspA gene in Lactococcus lactis NICE system and experimental study on its immunoreactivity. Gastroenterol Res Pract. 2015;2015:750932.

72. Martinez-Cuesta MC, Gasson MJ, Narbad A. Heterologous expression of the plant coumarate: coA ligase in Lactococcus lactis. Lett Appl Microbiol. 2005;40:44-9.

73. Dong Z, Zhang J, Li H, Du G, Chen J, Lee B. Codon and propeptide optimizations to improve the food-grade expression of bile salt hydrolase in Lactococcus lactis. Protein Pept Lett. 2015;22:727-35.

74. Yang Y, Kang Z, Zhou J, Chen J, Du G. High-level expression and characterization of recombinant acid urease for enzymatic degradation of urea in rice wine. Appl Microbiol Biotechnol. 2015;99:301-8.

75. Steidler L, Hans W, Schotte L, Neirynck S, Obermeier F, Falk W, Fiers W, Remaut $E$. Treatment of murine colitis by Lactococcus lactis secreting interleukin-10. Science. 2000;289:1352-5.

76. Braat H, Rottiers P, Hommes DW, Huyghebaert N, Remaut E, Remon JP, van Deventer SJ, Neirynck S, Peppelenbosch MP, Steidler L. A phase I trial with transgenic bacteria expressing interleukin-10 in Crohn's disease. Clin Gastroenterol Hepatol. 2006;4:754-9.

77. Steidler L, Neirynck S, Huyghebaert N, Snoeck V, Vermeire A, Goddeeris $B$, Cox E, Remon JP, Remaut E. Biological containment of genetically modified Lactococcus lactis for intestinal delivery of human interleukin 10. Nature Biotechnol. 2003;21:785-9.

78. de Moreno de LeBlanc A, del Chatel S, Chatel JM, Miyoshi A, Azevedo V, Langella P, Bermudez-Humaran LG, LeBlanc JG. Current review of genetically modified lactic acid bacteria for the prevention and treatment of colitis using murine models. Gastroenterol Res Pract. 2015;2015:146972.

79. Frossard CP, Steidler L, Eigenmann PA. Oral administration of an IL-10-secreting Lactococcus lactis strain prevents food-induced lgE sensitization. J Allergy Clin Immunol. 2007;1 19:952-9.

80. Wu C, Yang G, Bermudez-Humaran LG, Pang Q, Zeng Y, Wang J, Gao X. Immunomodulatory effects of $\mathrm{IL}-12$ secreted by Lactococcus lactis on Th1/Th2 balance in ovalbumin (OVA)-induced asthma model mice. Int Immunopharmacol. 2006;6:610-5.

81. Bermudez-Humaran LG, Langella P, Cortes-Perez NG, Gruss A, TamezGuerra RS, Oliveira SC, Saucedo-Cardenas O, Montes de Oca-Luna R, Le Loir Y. Intranasal immunization with recombinant Lactococcus lactis secreting murine interleukin-12 enhances antigen-specific Th1 cytokine production. Infect Immun. 2003;71:1887-96.

82. Bermudez-Humaran LG, Motta JP, Aubry C, Kharrat P, Rous-Martin L, Sallenave JM, Deraison C, Vergnolle N, Langella P. Serine protease inhibitors protect better than IL-10 and TGF-beta anti-inflammatory cytokines against mouse colitis when delivered by recombinant lactococci. Microb Cell Fact. 2015;14:26.

83. Liu S, Li Y, Deng B, Xu Z. Recombinant Lactococcus lactis expressing porcine insulin-like growth factor I ameliorates DSS-induced colitis in mice. BMC Biotechnol. 2016;16:25.

84. Kim JI, Park TE, Maharjan S, Li HS, Lee HB, Kim IS, Piao D, Lee JY, Cho CS, Bok JD, et al. Soluble RANKL expression in Lactococcus lactis and investigation of its potential as an oral vaccine adjuvant. BMC Immunol. 2015;16:71.

85. Glenting J, Poulsen LK, Kato K, Madsen SM, Frokiaer H, Wendt C, Sorensen HW. Production of recombinant peanut allergen Ara h 2 using Lactococcus lactis. Microb Cell Fact. 2007;6:28.

86. Daniel C, Repa A, Wild C, Pollak A, Pot B, Breiteneder H, Wiedermann $U$, Mercenier A. Modulation of allergic immune responses by mucosal application of recombinant lactic acid bacteria producing the major birch pollen allergen Bet v 1. Allergy. 2006;61:812-9.

87. Zhang $\mathrm{Q}, \mathrm{Ai}$ C. Development of house dust mite vaccine. Methods $\mathrm{Mol}$ Biol. 2016;1403:739-51.

88. Zhang B, Li A, Zuo F, Yu R, Zeng Z, Ma H, Chen S. Recombinant Lactococcus lactis NZ9000 secretes a bioactive kisspeptin that inhibits proliferation and migration of human colon carcinoma HT-29 cells. Microb Cell Fact. 2016;15:102.

89. Durmaz E, Hu Y, Aroian RV, Klaenhammer TR. Intracellular and extracellular expression of Bacillus thuringiensis crystal protein Cry5B in Lactococcus lactis for use as an anthelminthic. Appl Environ Microbiol. 2016;82:1286-94.
90. Liu KF, Liu XR, Li GL, Lu SP, Jin L, Wu J. Oral administration of Lactococcus lactis-expressing heat shock protein 65 and tandemly repeated IA2P2 prevents type 1 diabetes in NOD mice. Immunol Lett. 2016;174:28-36.

91. Dhakal R, Bajpai VK, Baek KH. Production of gaba (gamma-aminobutyric acid) by microorganisms: a review. Braz J Microbiol. 2012;43:1230-41.

92. Schuller HM, Al-Wadei HA, Majidi M. GABA B receptor is a novel drug target for pancreatic cancer. Cancer. 2008;112:767-78.

93. Li H, Cao Y. Lactic acid bacterial cell factories for gamma-aminobutyric acid. Amino Acids. 2010;39:1107-16.

94. Nomura M, Kimoto H, Someya Y, Suzuki I. Novel characteristic for distinguishing Lactococcus lactis subsp. lactis from subsp. cremoris. Int J Syst Bacteriol. 1999;49(Pt 1):163-6.

95. Pouwels PH, Leer RJ, Shaw M, Heijne den Bak-Glashouwer MJ, Tielen FD, Smit E, Martinez B, Jore J, Conway PL. Lactic acid bacteria as antigen delivery vehicles for oral immunization purposes. Int J Food Microbiol. 1998;41:155-67.

96. Norton PM, Brown HW, Wells JM, Macpherson AM, Wilson PW, Le Page RW. Factors affecting the immunogenicity of tetanus toxin fragment C expressed in Lactococcus lactis. FEMS Immunol Med Microbiol. 1996;14:167-77.

97. Steidler L, Robinson K, Chamberlain L, Schofield KM, Remaut E, Le Page RW, Wells JM. Mucosal delivery of murine interleukin-2 (IL-2) and IL-6 by recombinant strains of Lactococcus lactis coexpressing antigen and cytokine. Infect Immun. 1998;66:3183-9.

98. Bahey-El-Din M, Gahan CG. Lactococcus lactis-based vaccines: current status and future perspectives. Hum Vaccines. 2011;7:106-9.

99. Bermudez-Humaran LG, Kharrat P, Chatel JM, Langella P. Lactococci and lactobacilli as mucosal delivery vectors for therapeutic proteins and DNA vaccines. Microb Cell Fact. 2011;10(Suppl 1):S4.

100. Tarahomjoo S. Development of vaccine delivery vehicles based on lactic acid bacteria. Mol Biotechnol. 2012;51:183-99.

101. Bermudez-Humaran LG, Cortes-Perez NG, Lefevre F, Guimaraes V, Rabot S, Alcocer-Gonzalez JM, Gratadoux JJ, Rodriguez-Padilla C, TamezGuerra RS, Corthier G, et al. A novel mucosal vaccine based on live lactococci expressing E7 antigen and IL-12 induces systemic and mucosal immune responses and protects mice against human papillomavirus type 16-induced tumors. J Immunol. 2005;175:7297-302.

102. Zhang X, Hu S, Du X, Li T, Han L, Kong J. Heterologous expression of carcinoembryonic antigen in Lactococcus lactis via LcsB-mediated surface displaying system for oral vaccine development. J Microbiol Immunol Infect. 2014.

103. Freires IA, Aviles-Reyes A, Kitten T, Simpson-Haidaris PJ, Swartz M, Knight PA, Rosalen PL, Lemos JA, Abranches J. Heterologous expression of Streptococcus mutans Cnm in Lactococcus lactis promotes intracellular invasion, adhesion to human cardiac tissues and virulence. Virulence. 2016;104:1-12.

104. De Azevedo M, Santos Rocha C, Pereira V, De Junior AD, De Sousa CS, Azevedo V, LeBlanc JG, Chatel JM, Miyoshi A. Prospective uses of recombinant Lactococcus lactis expressing both listeriolysin $\mathrm{O}$ and mutated internalin A from Listeria monocytogenes as a tool for DNA vaccination. Genet Mol Res. 2015;14:18485-93.

105. Lei $H$, Peng $X$, Jiao $H$, Zhao D, Ouyang J. Broadly protective immunity against divergent influenza viruses by oral co-administration of Lactococcus lactis expressing nucleoprotein adjuvanted with cholera toxin B subunit in mice. Microb Cell Fact. 2015;14:111.

106. Lei H, Peng X, Ouyang J, Zhao D, Jiao H, Shu H, Ge X. Protective immunity against influenza $\mathrm{H} 5 \mathrm{~N} 1$ virus challenge in chickens by oral administration of recombinant Lactococcus lactis expressing neuraminidase. BMC Vet Res. 2015;11:85.

107. Lei H, Peng X, Ouyang J, Zhao D, Jiao H, Shu H, Ge X. Intranasal immunization of recombinant Lactococcus lactis induces protection against H5N1 virus in ferrets. Virus Res. 2015;196:56-9.

108. Lei H, Peng X, Shu H, Zhao D. Intranasal immunization with live recombinant Lactococcus lactis combined with heat-labile toxin B subunit protects chickens from highly pathogenic avian influenza H5N1 virus. J Med Virol. 2015;87:39-44.

109. Lei $H, X u Y, C$ Chen J, Wei X, Lam DM. Immunoprotection against influenza H5N1 virus by oral administration of enteric-coated recombinant Lactococcus lactis mini-capsules. Virology. 2010;407:319-24.

110. Lei H, Sheng Z, Ding Q, Chen J, Wei X, Lam DM, Xu Y. Evaluation of oral immunization with recombinant avian influenza virus $\mathrm{HA} 1$ displayed on 
the Lactococcus lactis surface and combined with the mucosal adjuvant cholera toxin subunit B. Clin Vaccine Immunol. 2011;18:1046-51.

111. Joan SS, Pui-Fong J, Song AA, Chang LY, Yusoff K, AbuBakar S, Rahim RA. Oral vaccine of Lactococcus lactis harbouring pandemic H1N1 2009 haemagg lutinin 1 and nisP anchor fusion protein elevates anti-HA1 slgA levels in mice. Biotechnol Lett. 2016;38:793-9.

112. Reese KA, Lupfer C, Johnson RC, Mitev GM, Mullen VM, Geller BL, Pastey $\mathrm{M}$. A novel lactococcal vaccine expressing a peptide from the M2 antigen of $\mathrm{H} 5 \mathrm{~N} 2$ highly pathogenic avian influenza A virus prolongs survival of vaccinated chickens. Vet Med Int. 2013;2013:316926.

113. Cao HP, Wang HN, Yang X, Zhang AY, Li X, Ding MD, Liu ST, Zhang ZK, Yang F. Lactococcus lactis anchoring avian infectious bronchitis virus multi-epitope peptide EpiC induced specific immune responses in chickens. Biosci Biotechnol Biochem. 2013;77:1499-504.

114. Kobierecka PA, Olech B, Ksiazek M, Derlatka K, Adamska I, Majewski PM, Jagusztyn-Krynicka EK, Wyszynska AK. Cell wall anchoring of the Campylobacter antigens to Lactococcus lactis. Front Microbiol. 2016;7:165.

115. Miyoshi A, Bermudez-Humaran LG, Ribeiro LA, Le Loir Y, Oliveira SC, Langella P, Azevedo V. Heterologous expression of Brucella abortus GroEL heat-shock protein in Lactococcus lactis. Microb Cell Fact. 2006;5:14.

116. Saez D, Fernandez P, Rivera A, Andrews E, Onate A. Oral immunization of mice with recombinant Lactococcus lactis expressing $\mathrm{Cu}, \mathrm{Zn}$ superoxide dismutase of Brucella abortus triggers protective immunity. Vaccine. 2012;30:1283-90.

117. Anuradha K, Foo HL, Mariana NS, Loh TC, Yusoff K, Hassan MD, Sasan $H$, Raha AR. Live recombinant Lactococcus lactis vaccine expressing aerolysin genes D1 and D4 for protection against Aeromonas hydrophila in tilapia (Oreochromis niloticus). J Appl Microbiol. 2010;109:1632-42.

118. Kim D, Beck BR, Lee SM, Jeon J, Lee DW, Lee Jl, Song SK. Pellet feed adsorbed with the recombinant Lactococcus lactis BFE920 expressing SiMA antigen induced strong recall vaccine effects against Streptococcus iniae infection in olive flounder (Paralichthys olivaceus). Fish Shellfish Immunol. 2016;55:374-83.

119. De Azevedo M, Meijerink M, Taverne N, Pereira VB, LeBlanc JG, Azevedo V, Miyoshi A, Langella P, Wells JM, Chatel JM. Recombinant invasive Lactococcus lactis can transfer DNA vaccines either directly to dendritic cells or across an epithelial cell monolayer. Vaccine. 2015;33:4807-12.

120. Almeida JF, Breyner NM, Mahi M, Ahmed B, Benbouziane B, Boas PC Miyoshi A, Azevedo V, Langella P, Bermudez-Humaran LG, Chatel JM. Expression of fibronectin binding protein A (FnBPA) from Staphylococcus aureus at the cell surface of Lactococcus lactis improves its immunomodulatory properties when used as protein delivery vector. Vaccine. 2016;34:1312-8.

121. Mutalib N, Isa N, Alitheen N, Song A, Rahim R. IRES-incorporated lactococcal bicistronic vector for target gene expression in a eukaryotic system. Plasmid. 2014;73:26-33.

122. Yagnik B, Padh H, Desai P. Construction of a new shuttle vector for DNA delivery into mammalian cells using non-invasive Lactococcus lactis. Microb Infect. 2016;18:237-44.

123. Li HS, Piao DC, Jiang T, Bok JD, Cho CS, Lee YS, Kang SK, Choi YJ. Recombinant interleukin 6 with M cell-targeting moiety produced in Lactococcus lactis IL 1403 as a potent mucosal adjuvant for peroral immunization. Vaccine. 2015;33:1959-67.

124. Ma L, Qiao X, Tang L, Jiang Y, Cui W, Li Y. Expression and biological activity of porcine interleukin-18 in recombinant Lactococcus lactis. Sheng Wu Gong Cheng Xue Bao. 2014;30:1541-8.

125. Huynh E, Li J. Generation of Lactococcus lactis capable of coexpressing epidermal growth factor and trefoil factor to enhance in vitro wound healing. Appl Microbiol Biotechnol. 2015;99:4667-77.

126. Shigemori S, Watanabe T, Kudoh K, Ihara M, Nigar S, Yamamoto Y, Suda Y, Sato T, Kitazawa H, Shimosato T. Oral delivery of Lactococcus lactis that secretes bioactive heme oxygenase-1 alleviates development of acute colitis in mice. Microb Cell Fact. 2015;14:189.

127. Roeffen $W$, Theisen $M$, van de Vegte-Bolmer M, van Gemert $G$, Arens $T$, Andersen G, Christiansen M, Sevargave L, Singh SK, Kaviraj S, Sauerwein R. Transmission-blocking activity of antibodies to Plasmodium falciparum GLURP.10C chimeric protein formulated in different adjuvants. Malar J. 2015;14:443.
128. Heine SJ, Franco-Mahecha OL, Chen X, Choudhari S, Blackwelder WC, van Roosmalen ML, Leenhouts K, Picking WL, Pasetti MF. Shigella $\mathrm{I} \mathrm{paB}$ and I $\mathrm{PaD}$ displayed on L. lactis bacterium-like particles induce protective immunity in adult and infant mice. Immunol Cell Biol. 2015;93:641-52.

129. Pereira VB, Saraiva TD, Souza BM, Zurita-Turk M, Azevedo MS, De Castro CP, Mancha-Agresti P, Dos Santos JS, Santos AC, Faria AM, et al. Development of a new DNA vaccine based on mycobacterial ESAT-6 antigen delivered by recombinant invasive Lactococcus lactis FnBPA+. Appl Microbiol Biotechnol. 2015;99:1817-26.

130. Kasarello K, Kwiatkowska-Patzer B, Lipkowski AW, Bardowski JK, Szczepankowska AK. Oral administration of Lactococcus lactis expressing synthetic genes of myelin antigens in decreasing experimental autoimmune encephalomyelitis in rats. Med Sci Monit. 2015;21:1587-97.

131. Robert S, Van Huynegem K, Gysemans C, Mathieu C, Rottiers P, Steidler L. Trimming of two major type 1 diabetes driving antigens, GAD65 and IA-2, allows for successful expression in Lactococcus lactis. Benef Microbes. 2015;6:591-601.

132. Ahmed B, Loos M, Vanrompay D, Cox E. Oral immunization with Lactococcus lactis-expressing EspB induces protective immune responses against Escherichia coli O157:H7 in a murine model of colonization. Vaccine. 2014:32:3909-16.

133. Li X, Xing Y, Guo L, Lv X, Song H, Xi T. Oral immunization with recombinant Lactococcus lactis delivering a multi-epitope antigen CTB-UE attenuates Helicobacter pylori infection in mice. Pathog Dis. 2014;72:78-86.

134. Chamcha V, Jones A, Quigley BR, Scott JR, Amara RR. Oral immunization with a recombinant Lactococcus lactis-expressing HIV-1 antigen on group A Streptococcus pilus induces strong mucosal immunity in the gut. J Immunol. 2015;195:5025-34.

135. Li PC, Qiao XW, Zheng QS, Hou JB. Immunogenicity and immunoprotection of porcine circovirus type 2 (PCV2) Cap protein displayed by Lactococcus lactis. Vaccine. 2016;34:696-702.

136. Samazan F, Rokbi B, Seguin D, Telles F, Gautier V, Richarme G, Chevret D, Varela PF, Velours C, Poquet I. Production, secretion and purification of a correctly folded staphylococcal antigen in Lactococcus lactis. Microb Cell Fact. 2015;14:104.

137. Veloso TR, Mancini S, Giddey M, Vouillamoz J, Que YA, Moreillon P, Entenza JM. Vaccination against Staphylococcus aureus experimental endocarditis using recombinant Lactococcus lactis expressing ClfA or FnbpA. Vaccine. 2015;33:3512-7.

138. Gao S, Li D, Liu Y, Zha E, Zhou T, Yue X. Oral immunization with recombinant hepatitis E virus antigen displayed on the Lactococcus lactis surface enhances ORF2-specific mucosal and systemic immune responses in mice. Int Immunopharmacol. 2015;24:140-5.

139. Guo S, Yan W, McDonough SP, Lin N, Wu KJ, He H, Xiang H, Yang M, Moreira MA, Chang YF. The recombinant Lactococcus lactis oral vaccine induces protection against $C$. difficile spore challenge in a mouse model. Vaccine. 2015;33:1586-95.

140. Lim SH, Jahanshiri F, Rahim RA, Sekawi Z, Yusoff K. Surface display of respiratory syncytial virus glycoproteins in Lactococcus lactis NZ9000. Lett Appl Microbiol. 2010;51:658-64.

141. Agarwal P, Khatri P, Billack B, Low WK, Shao J. Oral delivery of glucagon like peptide-1 by a recombinant Lactococcus lactis. Pharm Res. 2014;31:3404-14.

142. Berlec A, Jevnikar Z, Majhenic AC, Rogelj I, Strukelj B. Expression of the sweet-tasting plant protein brazzein in Escherichia coli and Lactococcus lactis: a path toward sweet lactic acid bacteria. Appl Microbiol Biotechnol. 2006;73:158-65.

143. Song AA, Abdullah JO, Abdullah MP, Shafee N, Othman R, Noor NM, Rahim RA. Engineering the lactococcal mevalonate pathway for increased sesquiterpene production. FEMS Microbiol Lett. 2014;355:177-84.

144. Bakari S, André F, Seigneurin-Berny D, Delaforge M, Rolland N, FreletBarrand A. Lactococcus lactis: recent developments in functional expression of membrane proteins. In membrane proteins production for structural analysis. New York: Springer; 2014.

145. Kunji ER, Slotboom DJ, Poolman B. Lactococcus lactis as host for overproduction of functional membrane proteins. Biochim Biophys Acta. 2003;1610:97-108. 
146. Bakari S, Lembrouk M, Sourd L, Ousalem F, Andre F, Orlowski S, Delaforge M, Frelet-Barrand A. Lactococcus lactis is an efficient expression system for mammalian membrane proteins involved in liver detoxification, CYP3A4, and MGST1. Mol Biotechnol. 2016;58:299-310.

147. Frelet-Barrand A, Boutigny S, Moyet L, Deniaud A, Seigneurin-Berny D, Salvi D, Bernaudat F, Richaud P, Pebay-Peyroula E, Joyard J, Rolland N. Lactococcus lactis, an alternative system for functional expression of peripheral and intrinsic Arabidopsis membrane proteins. PLOS ONE. 2010;5:e8746.

148. Bernaudat F, Frelet-Barrand A, Pochon N, Dementin S, Hivin P, Boutigny S, Rioux JB, Salvi D, Seigneurin-Berny D, Richaud P, et al. Heterologous expression of membrane proteins: choosing the appropriate host. PLoS ONE. 2011;6:e29191.

149. Xu Y, Kong J, Kong W. Improved membrane protein expression in Lactococcus lactis by fusion to Mistic. Microbiology. 2013;159:1002-9.

150. Kunji ER, Chan KW, Slotboom DJ, Floyd S, O'Connor R, Monne M Eukaryotic membrane protein overproduction in Lactococcus lactis. Curr Opin Biotechnol. 2005;16:546-51.

151. Henrich B, Klein JR, Weber B, Delorme C, Renault P, Wegmann U. Foodgrade delivery system for controlled gene expression in Lactococcus lactis. Appl Environ Microbiol. 2002;68:5429-36.
152. Simoes-Barbosa A, Abreu H, Silva Neto A, Gruss A, Langella P. A foodgrade delivery system for Lactococcus lactis and evaluation of inducible gene expression. Appl Microbiol Biotechnol. 2004;65:61-7.

153. Price CE, Zeyniyev A, Kuipers OP, Kok J. From meadows to milk to mucosa-adaptation of Streptococcus and Lactococcus species to their nutritional environments. FEMS Microbiol Rev. 2012;36:949-71.

154. van Veen H, Putman M, Margolles A, Sakamoto K, Konings W. Structurefunction analysis of multidrug transporters in Lactococcus lactis. Biochim Biophys Acta. 1999;1461:201-6.

155. Mathur S, Singh R. Antibiotic resistance in food lactic acid bacteria-a review. Int J Food Microbiol. 2005;105:281-95.

156. Cotter PD, Hill C, Ross RP. A food-grade approach for functional analysis and modification of native plasmids in Lactococcus lactis. Appl Environ Microbiol. 2003;69:702-6.

157. Bermudez-Humaran LG, Aubry C, Motta JP, Deraison C, Steidler L, Vergnolle N, Chatel JM, Langella P. Engineering lactococci and lactobacilli for human health. Curr Opin Microbiol. 2013;16:278-83.

158. Peterbauer C, Maischberger T, Haltrich D. Food-grade gene expression in lactic acid bacteria. Biotechnol J. 2011;6:1147-61.

\section{Submit your next manuscript to BioMed Central and we will help you at every step:}

- We accept pre-submission inquiries

- Our selector tool helps you to find the most relevant journal

- We provide round the clock customer support

- Convenient online submission

- Thorough peer review

- Inclusion in PubMed and all major indexing services

- Maximum visibility for your research

Submit your manuscript at www.biomedcentral.com/submit 